\title{
REDISCOVERY OF HYPSELOBARBUS PULCHELLUS, AN ENDEMIC AND THREATENED BARB (TELEOSTEI: CYPRINIDAE) OF THE WESTERN GHATS, WITH NOTES ON H. DOBSONI AND H. JERDONI
}

\section{J.D. Marcus Knight ${ }^{1}$, Ashwin Rai ${ }^{2} \&$ Ronald K.P. D'souza ${ }^{3}$}

${ }^{1}$ Flat L', Sri Balaji Apartments, $7^{\text {th }}$ Main Road, Dhandeeswaram, Velachery, Chennai, Tamil Nadu 600042, India

${ }^{2}$ Department of Fisheries Microbiology, College of Fisheries, Yekkur, Mangalore, Karnataka 575002, India

${ }^{3}$ Department of Applied Zoology, Mangalore University, Mangalagangothri, Mangalore, Karnataka 574199, India

1.jdmarcusknight@yahoo.co.in (corresponding author), ${ }^{2}$ winrai@yahoo.com, ${ }^{3}$ kevinroni@yahoo.com

\begin{abstract}
Hypselobarbus pulchellus, is a poorly known species, with very few verifiable records since its description in 1870 . Many authors have considered $H$. pulchellus to be a synonym of either $H$. dobsoni or $H$. jerdoni. This lack of information and clarity on its identity has led to $H$. pulchellus being categorized as a 'Critically Endangered' (possibly Extinct) species in the IUCN Red List of Threatened Species. Based on the collection of $H$. pulchellus from its type locality, we re-describe this little known species, and clear its taxonomic ambiguity vis-à-vis H. dobsoni and H. jerdoni.
\end{abstract}

Keywords: Barbus, Critically Endangered, Extinct, Gonoproktopterus, South Canara.

DOI: http://dx.doi.org/10.11609/JoTT.03686.5194-201 | ZooBank: urn:Isid:zoobank.org:pub:FBDC7B28-D7C6-4A24-A3A1-48230AB4E07A

Manuscript details: Ms \# 03686 | Received 01 July 2013 | Final received 10 December 2013 | Finally accepted 11 December 2013

Citation: Knight, J.D.M., A. Rai \& R.K.P. D'souza (2013). Rediscovery of Hypselobarbus pulchellus, an endemic and threatened barb (Teleostei: Cyprinidae) of the Western Ghats, with notes on H. dobsoni and H. jerdoni. Journal of Threatened Taxa 5(17): 5194-5201; http://dx.doi.org/10.11609/JoTT.o3686.5194-201

Copyright: (c) Knight et al. 2013. Creative Commons Attribution 3.0 Unported License. JoTT allows unrestricted use of this article in any medium, reproduction and distribution by providing adequate credit to the authors and the source of publication.

Funding: None

Competing Interest: The authors declare no competing interests.

Author Contribution: JDMK and AR carried out the study; AR and RKPD carried out field surveys and collected the lost species.

Author Details: DR. J.D. MARCUS KNIGHT is a naturalist based in Chennai. Amongst others, his interest is in exploring the freshwater habitats and is currently documenting the diversity of freshwater fish in southern India. DR. AsHWIN RAl is a Research Associate with the Department of Fisheries Microbiology, College of Fisheries and is involved in the study of aquatic ecology and biodiversity. In addition he is involved studies on the endemic fish's species of Western Ghats using DNA Barcoding. RoNALD K.P. D'souZA is currently doing his PhD at Mangalore University in the Department of Applied Zoology; his area of research is brood stock development, induced breeding and nursery rearing of selected species of Hypselobarbus with focus on $\mathrm{H}$. Jerdoni, H. lithopidos and $H$. thomassi.

Acknowledgements: We gratefully acknowledge the support provided by K. Venkataraman, Director, Zoological Survey of India, Kolkata; K. Ilango, Officer in Charge \& Jayasree Thilak, Scientist-C, Zoological Survey of India, Southern Regional Centre, Chennai. We thank Mark McGrouther and Amanda Hay of Australian Museum for providing us with photographs of syntypes. We acknowledge the support provided by the staff and personnel of Aquatic Biosystems, Mangalore, who helped in survey and collection in the river systems of Karnataka and Pramila Rajan, Jodi Fisheries, Chennai for the logistics that helped us transport these large barbs alive. Finally, we thank the anonymous reviewer(s) for the comments and criticism that helped substantially to improve the manuscript. 


\section{INTRODUCTION}

The enigmatic large barbs of the genus Hypselobarbus Bleeker, 1860 have always interested ichthyologists with several studies being carried out on their phylogeny and systematics (Mukerji 1931; Raj 1941; Jayaram 1997; Arunachalam et al. 2012; Pethiyagoda et al. 2012; Yang et al. 2012; Ali et al. 2013; Knight et al. 2013a,b). However, the identity of several species within this genus continues to remain ambiguous, with certain species presumed extinct due to the absence of any verifiable records since their description. One such poorly known species is Hypselobarbus pulchellus (Day, 1870), which has been categorized as 'Critically Endangered' (possibly Extinct) in the IUCN Red List of Threatened Species (Devi $\&$ Ali 2011) as a result of very few verifiable records since its description, including from the type locality, South Canara (Menon 2004).

There is also a considerable amount of taxonomic ambiguity surrounding the identity of $H$. pulchellus, with a few authors considering it as a junior synonym of either H. dobsoni or H. jerdoni (Hora \& Misra 1942; Jayaram 1991; Talwar \& Jhingran 1991; Jayaram 1999; Daniels 2002), while others suggesting that it is very difficult to distinguish $H$. pulchellus from $H$. dobsoni and $H$. jerdoni (Devi \& Ali 2011).

Like Hypselobarbus pulchellus, $H$. dobsoni is also a poorly known and documented species classified as 'Data Deficient' in the IUCN Red List (Raghavan \& Ali, 2011). Recently, there has been a speculation of the possibility of undescribed species being concealed within the genus Hypselobarbus (Arunachalam et al. 2012). This makes it imperative that the taxonomic identity and distribution of some of the already known species (for e.g., $H$. pulchellus, $H$. jerdoni and $H$. dobsoni) be cleared before additional species are described under this genus. Taxonomic studies on the genus Hypselobarbus is also imperative since most known species are threatened (Dahanukar et al. 2011), and their identities have to be cleared, before their populations decline further leading to possible extinction.

Recent surveys in South Canara = Dakshina Kannada led to the collection of specimens that matched the description of $H$. pulchellus. In this paper, we record this finding, redescribe this poorly known species and clear its taxonomic ambiguity vis-à-vis $H$. dobsoni and $H$. jerdoni.

\section{MATERIALS AND METHODS}

The materials used in the present study is based mostly on specimens collected during recent fieldwork in the Tunga, Sita and Netravathi rivers in southern Karnataka, and deposited in the Collections of the Zoological Survey of India, Southern Regional Centre, Chennai (ZSI/SRC) and the private collections of J.D. Marcus Knight (MKC). Quantification of characters follows Kottelat (2001). Measurements were taken using a digital caliper to the nearest $0.01 \mathrm{~mm}$ and rounded to $0.1 \mathrm{~mm}$, except for measurements of standard length, which were measured with a ruler to the nearest $1 \mathrm{~mm}$. Subunits of the head are expressed in proportions of head length $(\mathrm{HL})$. Numbers in parenthesis after a count denote the frequency of that count. Specimens were examined and/or dissected under a Magnüs binocular dissection micropcope. Osteological procedures follow Miranda \& Escala (2005). Photographs were taken with an Olympus SP570 UZ digital camera using supermacro mode. Specimens of $H$. pulchellus and $H$. jerdoni were collected from Dakshina Kannada = South Canara, their type locality and are topotypes. In the original description Day (1876) does not provide the type locality for $H$. dobsoni but Day (1878) mentions that, "Deccan from whence Dr. A.J. Dobson sent me specimens; I likewise obtained this species at Kurnool, in September, 1866, and also at Poona." As Kurnool lies on the banks of Tungabhadra River, in the present study we used $H$. dobsoni from Tunga River as comparative material. Photographs of the syntypes of both $H$. jerdoni and $H$. dobsoni from the Australian Museum, Sydney (AMS) and the photograph of a dry skin of $H$. pulchellus deposited by F. Day in the Natural History Museum, London (BMNH) were used to compare the general body shape and the lateral line scale count.

\section{Material examined}

Hypselobarbus pulchellus: ZSI/SRC F 8737, 20.iv.2013, 3 exs., 107.0-118.0 mm SL, Sita River, Karnataka, India, coll. Ronald D'souza; MKC 405, 20.iv.2013, 3 exs., 114.0208.0 mm SL, Sita River, Karnataka, India, coll. Ronald D'souza; ZSI/SRC F 8753, 1998, 1 ex., 126.0mm SL, Tunga River, Shimoga, Karnataka, India, coll. K.C. Jayaram.

Photograph: Barbus pulchellus: collected by F. Day, BMNH 1889.2.1.4328 (Dry skin) Canara. 


\section{Description}

Hypselobarbus pulchellus (Day, 1870)

Barbus (Barbodes) pulchellus Day, 1870

Puntius pulchellus (Day, 1870)

Gonoproktopterus pulchellus (Day, 1870)

Morphometric data is given in Table 1. General body shape and appearance as in Image 1 A-D. Body deep, laterally compressed; dorsal contour ascending sharply, with a clear indentation at nape and tapering gradually posterior to dorsal-fin insertion; ventral profile deep and equally convex, curving up to anal-fin origin, thence sloping upward towards caudal peduncle; caudal peduncle deep, its depth almost equal to its length, concave in both dorsal and ventral profiles. Head short, snout rounded with an indention at the end anterior to the nares. Mouth inferior, lips thick, lateral fold on the snout present. Barbels 4, a maxillary pair (approximately 24-38 \% HL) and a rostral pair (approximately 13-20\% $\mathrm{HL}$ ). Eye large, placed on the upper half of the head, approximately $29-40 \%$ HL. Dorsal-fin with 3 simple and $91 / 2$ branched rays, the last simple ray weak. Dorsalfin origin slightly anterior to pelvic-fin origin, inserted midway between tip of snout and base of caudal fin. Pelvic fin with 1 simple and 8(6)-9(1) branched rays. Anal fin with 3 simple and $51 / 2$ branched rays. Pectoral fin with 1 simple and 15(5)-16(2) branched rays. Pectoral and pelvic fins short, not reaching pelvic and anal-fin origins respectively. Caudal fin with $19(1+9+8+1)$ rays, deeply forked. Lateral line complete, with 32(1), 33(2) and $34(4)+1(2)-2(5)$ scales on the caudal fin base.

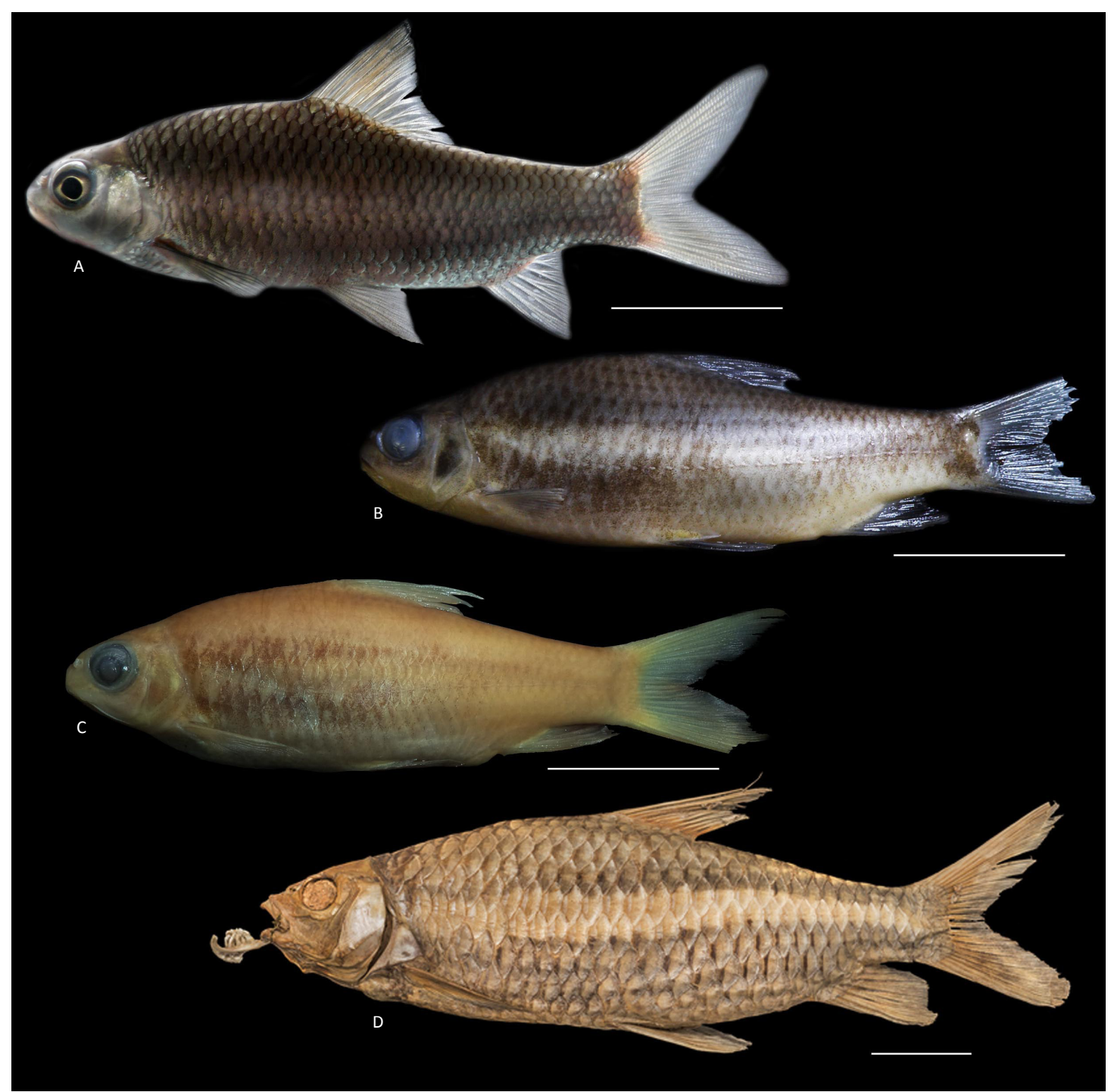

Image1. Hypselobarbus pulchellus: A - Sita River, Karnataka, unregistered live specimen (@ J.D.M. Knight); B- Sita River, Karnataka, formalin fixed specimen (MKC 405) (@ J.D.M. Knight); C - Tunga River, Karnataka, collected by K.C. Jayaram (ZSI SRC F 8753) (৫ J.D.M. Knight); D- Collected by F. Day,(BMNH 1889.2.1.4328) (Dry skin), Canara (@ http://www.nhm.ac.uk). Scale bar=50 mm. 
Table 1. Biometric and meristic data of Hypselobarbus pulchellusfrom Sita, Karnataka (ZSI/SRC F8737, 3 exs. and MKC 405, 3 ex.) and Tunga River, Karnataka (ZSI/SRC F 8753, 1 ex.); H. dobsoni from Tunga River, Karnataka (ZSI/SRC F8738, 1 exs. and MKC406, 2 ex.) and H. jerdoni, Netravathi River, Karnataka (ZSI/SRC F8739, 2 exs and MKC 407, 3 exs.)

\begin{tabular}{|c|c|c|c|c|c|c|}
\hline \multirow{2}{*}{ Character } & \multicolumn{2}{|c|}{ H. pulchellus } & \multicolumn{2}{|c|}{ H. dobsoni } & \multicolumn{2}{|c|}{ H. jerdoni } \\
\hline & Range & Mean \pm SD & Range & Mean \pm SD & Range & Mean \pm SD \\
\hline Standard length $(\mathrm{mm})$ & \multicolumn{2}{|c|}{$107.0-208.0$} & \multicolumn{2}{|c|}{$115.0-152.0$} & \multicolumn{2}{|c|}{$71.0-145.0$} \\
\hline \multicolumn{7}{|l|}{$\% \mathrm{SL}$} \\
\hline Head length & $20.4-23.1$ & $21.7 \pm 1.2$ & $22.1-22.9$ & $22.5 \pm 0.3$ & $22.7-25.7$ & $23.6 \pm 1.3$ \\
\hline Head depth & $17.2-19.4$ & $18.6 \pm 0.9$ & $18.1-18.9$ & $18.6 \pm 0.4$ & $17.3-20.2$ & $18.3 \pm 1.1$ \\
\hline Head width & $11.2-12.7$ & $11.9 \pm 0.7$ & $14.5-15.7$ & $15.0 \pm 0.6$ & $13.0-14.6$ & $13.9 \pm 0.5$ \\
\hline Snout length & $6.3-7.4$ & $7.2 \pm 0.6$ & $8.0-8.5$ & $8.3 \pm 0.2$ & $7.8-9.4$ & $8.5 \pm 0.7$ \\
\hline Orbit diameter & $5.8-8.2$ & $7.1 \pm 1.2$ & $7.0-8.3$ & $7.7 \pm 0.7$ & $6.6-9.5$ & $7.6 \pm 1.1$ \\
\hline Interorbital width & $9.7-11.7$ & $10.8 \pm 1.0$ & $10.0-11.1$ & $10.4 \pm 0.5$ & $9.5-10.4$ & $9.9 \pm 0.3$ \\
\hline Internarial width & $6.0-7.1$ & $6.2 \pm 0.4$ & $5.7-6.0$ & $5.9 \pm 0.1$ & $5.4-6.3$ & $5.8 \pm 0.3$ \\
\hline Body depth & $29.9-35.5$ & $32.4 \pm 2.2$ & $28.7-31.8$ & $30.4 \pm 1.5$ & $32.9-38.6$ & $35.3 \pm 2.4$ \\
\hline Body width & $15.6-17.6$ & $16.4 \pm 1.0$ & $18.0-19.3$ & $18.6 \pm 0.7$ & $15.0-16.4$ & $15.8 \pm 0.5$ \\
\hline Predorsal length & $50.0-51.2$ & $50.6 \pm 0.6$ & $48.2-49.3$ & $48.8 \pm 0.5$ & $48.8-51.0$ & $50.2 \pm 0.9$ \\
\hline Dorsal to hypural length & $45.1-53.2$ & $49.1 \pm 3.2$ & $49.6-53.0$ & $51.3 \pm 1.7$ & $48.0-54.0$ & $51.0 \pm 2.3$ \\
\hline Caudal peduncle length & $14.9-17.2$ & $15.9 \pm 1.1$ & $14.6-16.5$ & $15.6 \pm 0.9$ & $11.2-14.2$ & $13.1 \pm 1.2$ \\
\hline Caudal peduncle depth & $14.4-17.1$ & $15.1 \pm 1.5$ & $14.3-15.4$ & $14.8 \pm 0.5$ & $16.0-18.4$ & $17.0 \pm 0.9$ \\
\hline Prepelvic length & $47.2-49.8$ & $48.6 \pm 1.4$ & $47.8-52.3$ & $49.6 \pm 2.5$ & $49.1-55.7$ & $51.7 \pm 2.7$ \\
\hline Dorsal fin length & $20.7-23.3$ & $22.0 \pm 1.0$ & $21.5-25.2$ & $23.0 \pm 2.0$ & $26.4-30.1$ & $28.4 \pm 1.5$ \\
\hline Anal fin length & $16.6-20.1$ & $18.5 \pm 1.8$ & $16.3-19.0$ & $17.8 \pm 1.3$ & $20.4-21.3$ & $21.1 \pm 0.3$ \\
\hline Pelvic fin length & $16.8-20.5$ & $18.6 \pm 1.4$ & $16.9-19.4$ & $18.1 \pm 1.2$ & $20.7-22.6$ & $21.6 \pm 0.8$ \\
\hline Length of maxillary barbel & $5.1-7.9$ & $6.8 \pm 1.9$ & $4.4-6.9$ & $5.5 \pm 1.1$ & $6.6-8.5$ & $7.4 \pm 0.7$ \\
\hline Length of rostral barbel & $2.8-3.8$ & $3.5 \pm 0.7$ & $2.8-3.6$ & $3.2 \pm 0.3$ & $4.6-5.0$ & $4.8 \pm 0.1$ \\
\hline \multicolumn{7}{|l|}{$\% \mathrm{HL}$} \\
\hline Head depth & $78.4-89.1$ & $84.9 \pm 3.9$ & $81.8-84.1$ & $82.8 \pm 1.2$ & $69.9-89.0$ & $78.3 \pm 6.9$ \\
\hline Head width & $53.6-70.5$ & $61.1 \pm 7.8$ & $65.5-68.7$ & $66.9 \pm 1.7$ & $56.8-61.6$ & $59.5 \pm 2.3$ \\
\hline Snout length & $32.3-33.8$ & $33.5 \pm 0.6$ & $35.5-38.2$ & $36.9 \pm 1.3$ & $34.1-40.9$ & $36.7 \pm 2.6$ \\
\hline Orbit diameter & $29.0-39.8$ & $34.2 \pm 4.9$ & $31.7-37.0$ & $34.6 \pm 2.7$ & $29.1-37.1$ & $32.3 \pm 3.0$ \\
\hline Interorbital width & $44.3-53.6$ & $48.9 \pm 4.0$ & $45.1-47.9$ & $46.3 \pm 1.5$ & $40.4-43.9$ & $42.3 \pm 2.9$ \\
\hline Internarial width & $28.0-32.2$ & $30.6 \pm 1.8$ & $25.8-26.5$ & $26.1 \pm 0.3$ & $22.9-27.4$ & $25.0 \pm 1.8$ \\
\hline Length of maxillary barbel & $23.9-37.6$ & $29.3 \pm 4.9$ & $20.1-29.1$ & $24.3 \pm 4.5$ & $28.4-37.6$ & $32.1 \pm 3.8$ \\
\hline Length of rostral barbel & $12.8-20.0$ & $16.2 \pm 2.8$ & $13.0-16.1$ & $14.5 \pm 1.5$ & $18.0-22.1$ & $20.6 \pm 1.6$ \\
\hline \multicolumn{7}{|l|}{ Meristics } \\
\hline Lateral line scales & \multicolumn{2}{|c|}{$32(1), 33(2), 34(4)+1(2)-2(5)$} & \multicolumn{2}{|c|}{$30(2)-31(1)+1$} & \multicolumn{2}{|c|}{$29(1)-30(4)+1$} \\
\hline Lateral transverse & \multicolumn{2}{|c|}{$1 / 26(1)-6(6) / 1 / 3(2)-31 / 2(5)$} & \multicolumn{2}{|c|}{$6(1)-1 / 25(2) / 1 / 3$} & \multicolumn{2}{|c|}{$1 / 25 / 1 / 3$} \\
\hline Dorsal fin & \multicolumn{2}{|c|}{ iii, $9 \frac{112}{2}$} & \multicolumn{2}{|c|}{ iii, $9 \frac{112}{2}$} & \multicolumn{2}{|c|}{ iii, $9 \frac{1}{2}$} \\
\hline Pelvic fin & \multicolumn{2}{|c|}{$\mathrm{i}, 8(6)-9(1)$} & \multicolumn{2}{|c|}{$\mathrm{i}, 8$} & \multicolumn{2}{|c|}{$\mathrm{i}, 8$} \\
\hline Pectoral fin & \multicolumn{2}{|c|}{ i, 15(5)-16(2) } & \multicolumn{2}{|c|}{$\mathrm{i}, 14(1)-15(2)$} & \multicolumn{2}{|c|}{$\mathrm{i}, 15$} \\
\hline Anal fin & & & & & & \\
\hline Caudal fin & & & & & & \\
\hline Pre-dorsal scales & & & & & & \\
\hline Gill rakers & $4(4), 5(2)$ & $11(6), 12(1)$ & $3(1)$ & +10 & $3+10$ & $11(1)$ \\
\hline
\end{tabular}


Transverse scales from dorsal-fin origin to ventral fin origin $1 / 26(1)-6(6) / 1 / 3(2)-3 \frac{1}{2}(5)$. Predorsal scales $11(4)-$ $12(3)$ and 14 circumpeduncular scales. Pelvic axillary scale present. Gill rakers 4(4), 5(2), 6(1)+11(6), 12(1) on the first gill arch.

\section{Colouration}

In life, dark grey above and light grey below with a silver or bronze coloured band running across the length of the body two scales high, which include the lateral line scale row and one scale row above it. Head silvery white and all fins dusky grey (Image 1A). Formalin-fixed and alcohol-preserved specimens are dark grey with the lateral band becoming white in colour. All fins dark grey (Image 1B). The light coloured band running along the lateral line is also clearly perceivable in the dry skin mount of $H$. pulchellus in the Natural History Museum, London (BMNH 1889.2.1.4328) (Image 1D).

\section{Distribution}

Hypselobarbus pulchellus is currently known from Sita and Tunga rivers, Shimoga in the South Canara region of the southern Western Ghats.

\section{DISCUSSION}

Barbus (Barbodes) pulchelus currently designated to the Genus Hypselobarbus (Rainboth 1989; Menon 1992; Arunachalam et al. 2012; Yang et al. 2012; Knight et al. 2013b) was described by Day (1870) from South Canara, India (Day 1878). Though there have been sporadic reports of this species from the Western Ghats (Rajan 1955; David 1956; David et al. 1967; David et al. 1970; David \& Rajagopal 1975; Mohanta et al. 2008), its identity was either considered unclear (Devi \& Ali 2011) or the species was considered a synonym of either H. dobsoni or H. jerdoni (Hora \& Misra 1942; Jayaram 1991; Talwar \& Jhingran 1991; Jayaram 1999; Daniels 2002). As all these reports were either a part of natural history or fishery studies, they lacked the description or the voucher specimen of the fish identified as $H$. pulchellus, thereby providing no clarity on the identity of this enigmatic barb. This lack of information and clarity on its identity eventually led to $H$. pulchellus being categorized as a 'Critically Endangered' (and possibly Extinct) (Devi \& Ali 2011). Even the description of $H$. pulchellus in a recent report (Shrivana 2013) pointed towards $H$. dobsoni instead, highlighting the fact that there is significant confusion on the identity of these species. Moreover, Arunachalam et al. (2012) while highlighting the possibility of undescribed species being concealed within this genus, overlooked both $\mathrm{H}$. dobsoni and $H$. pulchellus in their work. As $H$. pulchellus has been listed as 'Critically Endangered' (possibly Extinct) (Devi \& Ali 2011) it is important to fill in knowledge gaps on its identity and status, before additional species are described under Hypselobarbus and the already extant species are forgotten in time.

Hypselobarbus pulchellus can be distinguished clearly from both $H$. dobsoni and $H$. jerdoni, based on a silver or bronze coloured band running across the length of the body two scales high, which include the lateral line scale row and one scale row above it (vs. absence of the band in $H$. dobsoni and $H$. jerdoni). Dorsal fin, pelvic fin and caudal fin tips devoid of any markings (Image 1A) (vs. distal portion of the dorsal fin black, with pelvic fin tips and caudal fin tips black in $\mathrm{H}$. dobsoni and H. jerdoni (Image $2 \mathrm{~A} \& \mathrm{C})$ ). Furthermore, H. pulchellus can be distinguished by a higher lateral line scale count of 32-34+1-2 (vs. 30-31+1 scales in H. dobsoni and 29-30 +1 scales in $H$. jerdoni), higher transverse scale count of $1 / 26-6 / 1 / 3-31 / 2$ (vs. $1 / 25 / 1 / 3$ in $H$. dobsoni and $H$. jerdoni). Hypselobarbus pulchellus has a lesser head width of 11.2-12.7 \% SL (vs. 14.5-15.7\% SL in H. dobsoni and 13.0-14.6\% SL in $H$. jerdoni); shorter snout length of 6.3-7.4 \% SL (vs. 8.0-8.5 \% SL in H. dobsoni and 7.89.4\% SL in H. jerdoni); lesser body width of 15.6-17.6 \% SL (vs. 18.0-19.3\% SL in $H$. dobsoni) and greater predorsal length of 50.0-51.2 \% SL (vs. 48.2-49.3\% SL in $H$. dobsoni). In addition, $H$. pulchellus has large thick teeth on the fifth ceratobranchial (Image $3 A$ ) vs. short slender teeth in $\mathrm{H}$. dobsoni (Image 3B) and large teeth with hook shaped tips in $\mathrm{H}$. jerdoni (Image $3 \mathrm{C}$ ).

Interestingly, Jayaram et al. (1982) considered $H$. pulchellus as a valid species and remarked that though Hora \& Misra (1942) synonymised $H$. pulchellus with $H$. jerdoni, it could be clearly distinguished from the latter by a higher lateral line scale count of 30-35 and the relative length of the dorsal fin. During the course of the study, one specimen of $H$. pulchellus collected by Jayaram (ZSI/SRC F 8753) from Tunga River, Shimoga, Karnataka was examined. Similar to the other specimens of $H$. pulchellus collected from Sita River, Karnataka, the specimen from Tunga River, Shimoga collected by Jayaram had $33+2$ lateral line scales. Moreover, $H$. pulchellus can be distinguished from $H$. jerdoni based on a shorter dorsal fin length of 20.7-23.3\% SL (vs. 26.4$30.1 \% \mathrm{SL}$ ) as observed by Jayaram et al. (1982).

Hypselobarbus pulchellus can further be distinguished from $H$. thomassi and by a higher transverse scale row, $1 / 26-6 / 1 / 3-3 \frac{1}{2}$ (vs. $1 / 25 / 1 / 2 \frac{1}{2}-3$ ) and dark grey coloured 


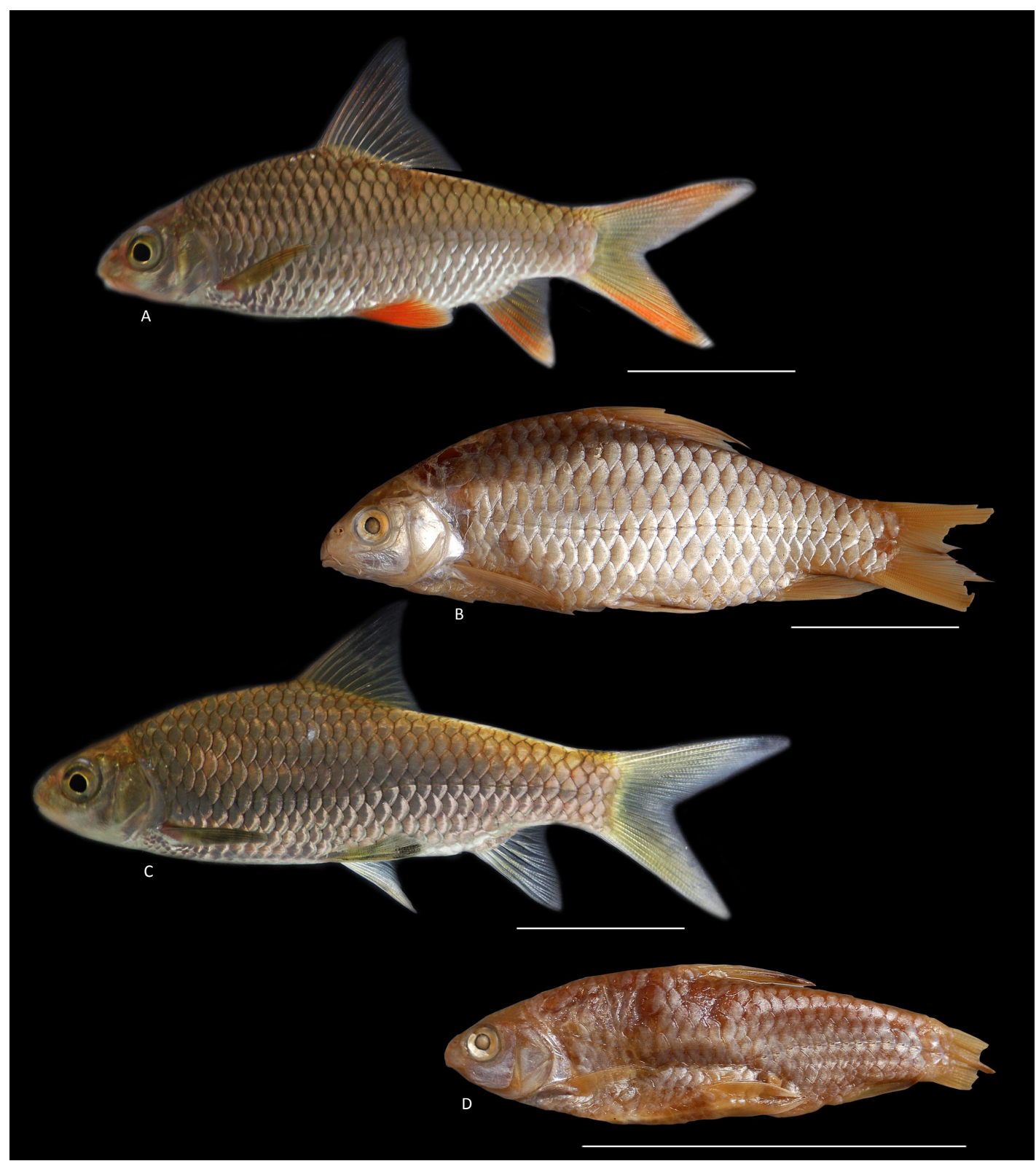

Image 2. Hypselobarbus jerdoni: A - Netravathi River, Karnataka (ZSI SRC F 8739 prior to fixation) (@ J.D.M. Knight); B - Syntype, AMS B.7935, Canara (@Mark McGrouther); Hypselobarbus dobsoni: C - Tunga River, Karnataka (ZSI SRC F 8738 prior to fixation) (@ J.D.M. Knight); D - Syntype, AMS B.7860, Poona (@Mark McGrouther). Scale bar $=50 \mathrm{~mm}$.

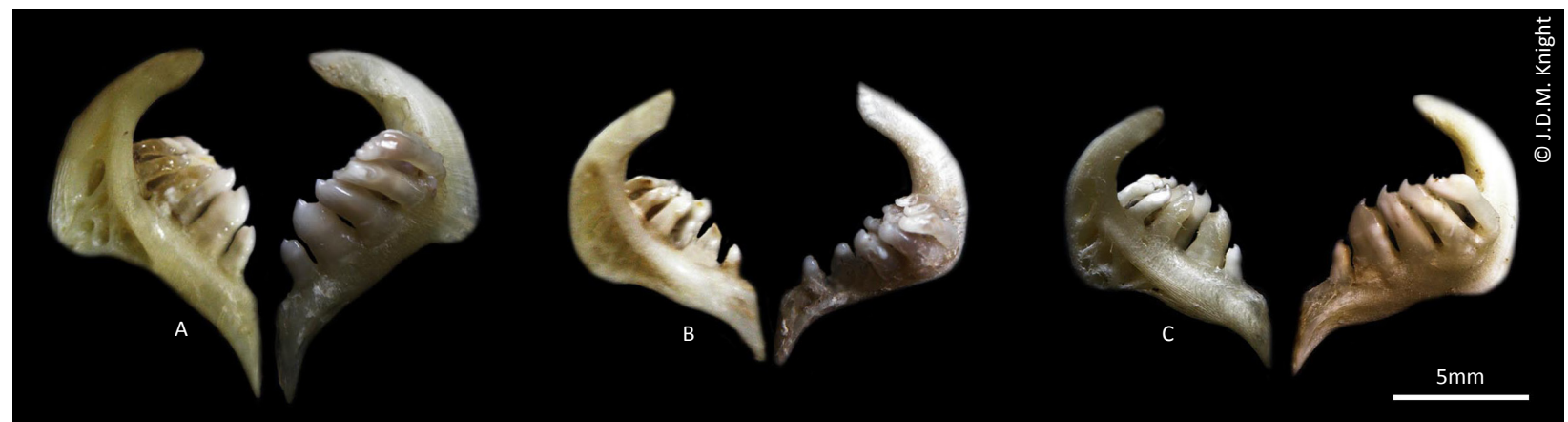

Image 3. Anterior and posterior view of the fifth ceratobranchial.

A - Hypselobarbus pulchellus; B - Hypselobarbus dobsoni; C - Hypselobarbus jerdoni 
body and fins (vs. reddish body and fins). It can also be distinguished from $\mathrm{H}$. lithopidos by a lesser lateral line scale count of 32-34+1-2 (vs. 37-38+1), lesser predorsal scales 11-12 (vs. 14-15) and lesser number of gill rakers 11-12 (vs. 14-15) in the lower arm of the first gill arch.

Hypselobarbus pulchellus can also be distinguished from $H$. micropogon, $H$. periyarensis and $H$. dubius by having its last simple dorsal ray weak and articulated vs. strong osseous (Jayaram 1991). It can be distinguished from $H$. curmuca and $H$. canarensis by a lower lateral line scale count of $32-34+1-2$ (vs. 41-44) and by the presence of two pairs of barbels (vs. one pair of barbels in H. curmuca) (Knight et al. 2013b) .

It is relevant to note that Hypselobarbus dobsoni and $H$. jerdoni were also considered synonyms by certain authors (Jayaram 1991; Talwar \& Jhingran 1991; Jayaram 1999; Daniels 2002). However, these two species can be clearly distinguished from each other by $H$. dobsoni having grey or pale yellow fins vs. $H$. jerdoni having bright orange or red fins. Hypselobarbus dobsoni can further be distinguished from $\mathrm{H}$. jerdoni based on a lesser body depth of 28.7-31.8\% SL (vs. 32.9-38.6\% SL); greater body width of 18.0-19.3 \% SL (vs. 15.0-16.4 $\% \mathrm{SL})$; greater caudal peduncle length of 15.0-16.4 \% SL (vs. 11.2-14.2\% SL); lesser caudal peduncle depth of 14.3-15.4 \% SL (vs. 16.0-18.4 \% SL); shorter dorsal fin length of 21.5-25.2 \% SL (vs. 26.4-30.1\% SL); shorter anal fin length of 16.3-19.0\% SL (vs. 20.4-21.3\% SL) and shorter pelvic fin length of 16.9-19.4 \% SL (vs. 20.7-22.6 $\% \mathrm{SL})$.

Day (1870) based his original description of $H$. pulchellus on a single stuffed specimen and mentioned 30 lateral line scales. Later Day (1878) redescribed the species based on two specimens and reported a lateral line scale count as 30-32. Even though Day (1878) does not mention whether the specimens were stuffed or not, the original description (Day 1870) was based on stuffed specimens and scale loss in stuffed specimen is quite inevitable. However, the specimens examined in this study had 32-34+1-2 lateral line scales. It is highly probable that one or two scales on the caudal fin base could have fallen off in the specimen that Day (1870) used for the original description. Moreover, the dry skin mount of $H$. pulchellus at the National History Museum, London (BMNH 1889.2.1.4328) does appear to have more than 32 lateral line scales. All other characters, including the unique colour pattern consisting of the silver or bronze coloured band running across the length of the body fit the description as provided by Day (1870, 1878).

Habitat loss as a result of dams and hydro-electric projects, together with other anthropogenic factors such as unmanaged exploitation often through the use of destructive fishing practices could be a probable reason for the decline in the population of these barbs (Devi \& Ali 2011). However, 'Wallacean shortfall' also has a part in certain species being presumed extinct (Knight 2010) which in this case is evident from the record of $H$. pulchellus from its type locality from where it was 'presumed' extinct.

\section{Comparative material}

Hypselobarbus dobsoni: ZSI/SRC F 8738, 12.v.2013, 1 exs., 152.0mm SL, Tunga River, Karnataka, India, coll. Ronald D'souza; MKC 406, 12.v.2013, 2 exs., 115.0130.0 mm SL, Tunga River, Karnataka, India Coll. Ronald D'souza.

Hypselobarbus jerdoni: ZSI/SRC F 8739, 06.i.2013, 2 exs., 75.0-145.0 mm SL, Netravathi River, Karnataka, India, coll. Ronald D'souza; MKC 407, 06.i.2013, 3 exs., 130.0-151.0 mm SL, Netravathi River, Karnataka, India, coll. Ronald D'souza.

Hypselobarbus thomassi: ZSI/SRC F 8664, 13.i.2013, 2 exs., 133-135 mm SL, Kempu Hole River, Karnataka, coll. Ashwin Rai; MKC 404, 13.i.2013, 1 ex., 213mm SL, Kempu Hole River, Karnataka, coll. Ashwin Rai; ZSI/SRC F 8665, 11.vii.2012, 1 ex. 132mm SL, Athirapally waterfalls, Chalakudy River, Kerala, coll. Pushpangathan.

Hypselobarbus lithopidos: ZSI/SRC F 8663, 14.x.2012, 2 exs., 105.0-135.0 mm SL, Phalguni River, Karnataka, India, coll. Ashwin Rai; MKC 403, 14.x.2012, 1 exs., 169.0mm SL, Phalguni River, Karnataka, India, coll. Ashwin Rai.

Hypselobarbus dubius: ZSI/SRC F5439, 18.xii.1997, 1 ex., 207mm SL, Amaravathy Dam, coll. M.S. Ravichandran.

Hypselobarbus micropogon: ZSI/SRC URC, 15.v.1996, 1 ex., 190mm SL, Nelambur (?), Wyanad, coll. A. Manimekalan.

Photographs: Barbus jerdoni, Syntype, AMS B.7935 (1,179mm) Canara (Image 2B); Barbus dobsoni, Syntype, AMS B.7860 (1, $62 \mathrm{~mm}$ ) Poona (Image 2D).

\section{REFERENCES}

Ali, A., S. Philip \& R. Raghavan (2013). Back from obscurity: notes on the current distribution, threats and conservation status of a poorly known cyprinid, Hypselobarbus lithopidos (Day, 1874) from the Western Ghats of India. Journal of Threatened Taxa 5(13): 47434751; http://dx.doi.org/10.11609/JoTT.03655.4743-51

Arunachalam, M., M. Raja, M. Muralidharan \& R.L. Mayden (2012). Phylogenetic relationships of species of Hypselobarbus (Cypriniformes: Cyprinidae): an enigmatic clade endemic to aquatic systems of India. Zootaxa 3499: 63-73. 
Bleeker, P. (1860). Conspectus systematis Cyprinorum. Natuurkundig Tijdschrift voor Nederlandsch-Indië 20: 421-441.

Dahanukar, N., R. Raghavan, A. Ali, R. Abraham \& C.P. Shaji (2011). The status and distribution of freshwater fishes of the Western Ghats. Chapter 3, pp. 21-48. In: Molur, S., Smith, K.G., Daniel, B.A. \& Darwall, W.R.T. (compilers). The Status and Distribution of Freshwater Biodiversity in The Western Ghats, India. Cambridge, UK and IUCN, Gland, Switzerland and Zoo Outreach Organisation, Coimbatore, India 116pp.

Daniels, R.J.R. (2002). Freshwater Fishes of Peninsular India. Universities Press, Hyderabad, India, 288pp.

David, A. (1956). Studies on the pollution of the Bhadra river fisheries at Bhadravti (Mysore State) with industrial effluents. Proceedings of the National Institute of Science, India 22: 132-160.

David, A., B.V. Govind, N.G.S. Rao \& K.V. Rajagopal (1967). Fish "seed" resources of some rivers in south India. Indian Journal of Fisheries 14 (1\&2): 54-84.

David, A., N.G.S. Rao \& M.F. Rahman (1970). A note on the harbivorous feeding of Puntius pulchellus (Day). Journal of Inland Fisheries Society of India 2: 159-160.

David, A. \& K.V. Rajagopal (1975). Food and feeding relationships of some commercial fishes of the Tungabhadra reservoir. Proceedings of the Indian National Science Academy 41(1): 61-74.

Day, F. (1870). Notes on some fishes from the western coast of India. Proceedings of the General Meetings for Scientific Business of the Zoological Society of London Pt(2): 369-374.

Day, F. (1876). On some of the fishes of the Deccan. The Journal of the Linnean Society of London 12(64): 565-578.

Day, F. (1878). The Fishes of India; Being a Natural History of the Fishes Known to Inhabit the Seas and Freshwaters of India, Burma and Ceylon. William Dawson\& Sons Ltd., London, $x x+778 p p, 196 p l s$.

Devi, K.R. \& A. Ali (2011). Hypselobarbus pulchellus. In: IUCN 2012. IUCN Red List of Threatened Species. Version 2012.2. <www. iucnredlist.org>. Downloaded on 12 April 2013.

Hora, S.L. \& K.S. Misra (1942). Fish of Poona, Part II. Journal of the Bombay Natural History Society 43(2): 218-225.

Jayaram, K.C., T. Venkateswarlu \& M.B. Ragunathan (1982). A Survey of the Cauvery River System with a Major Account of its Fish Fauna. Records of the Zoological Survey of India, Occasional Paper No. 36. $115 p p+12 p l s$.

Jayaram, K.C. (1991). Revision of the Genus Puntius Hamilton from the Indian region (Pisces: Cypriniformes, Cyprinidae, Cyprininae). Records of the Zoological Survey of India Occasional Paper 135 $1-178$

Jayaram, K.C. (1997). Nomenclature and systematic status of Barbus mussullah (Sykes, 1839). Journal of the Bombay Natural History Society 94(1): 48-55

Jayaram, K.C. (1999). The Freshwater Fishes of the Indian Region. Narendra Publishing House, New Delhi, India, 551pp.

Knight, J.D.M. (2010). Addressing the wallacean shortfall: an updated Checklist of Icthyofauna of Chembarampakkam tank. Taprobanica 2(1): 25-29; http://dx.doi.org/10.4038/tapro.v2i1.2704
Knight, J.D.M., A. Rai \& R.K.P. D'souza (2013a). Re-description of Hypselobarbus lithopidos (Teleostei: Cyprinidae), based on its rediscovery from the Western Ghats, India, with notes on $H$. thomassi. Journal of Threatened Taxa 5(13): 4734-4742; http:// dx.doi.org/10.11609/JoTT.o3602.4734-42

Knight, J.D.M., A. Rai \& R.K.P. D'souza (2013b). On the identities of Barbus mussullah Sykes and Cyprinus curmuca Hamilton with notes on the status of Gobio canarensis Jerdon (Teleostei: Cyprinidae). Zootaxa 3750 (3): 201-215

Kottelat, M. (2001). Fishes of Laos. WHT Publications Ltd., Colombo 5, Sri Lanka, 198pp.

Menon, A.G.K. (1992). Taxonomy of mahseer fishes of the genus Tor Gray with description of a new species from the Deccan. Journal of the Bombay Natural History Society 89(2): 210228.

Menon, A.G.K. (2004). Threatened Fishes of India and Their Conservation. Zoological Survey of India, Kolkata, 170pp.

Miranda, R. \& M.C. Escala (2005). Morphometrical comparison of cleithra, opercular and pharyngeal bones of autochthonous Leuciscinae (Cyprinidae) of Spain. Folia Zoologica 54(1-2): 173-188.

Mohanta, K.N., S. Subramanian, N. Komarpant \& S. Saurabh (2008). Alternate carp species for diversification in freshwater aquaculture in India. Aquaculture Asia 13(1): 11-15.

Mukerji, D.D. (1931). On a small collection of fish from the Bhavani River (S. India). Journal of Bombay Natural History Society 35(1): 162-171.

Pethiyagoda, R., M. Meegaskumbura \& K. Maduwage (2012). Synopsis of the South Asian fishes referred to Puntius (Pisces: Cyprinidae). Ichthyological Exploration of Freshwaters 23(1): 69-95.

Raghavan, R. \& A. Ali (2011). Hypselobarbus dobsoni. In: IUCN 2013. IUCN Red List of Threatened Species. Version 2013.2. <www. iucnredlist.org>. Downloaded on 09 December 2013.

Rainboth, W.J. (1989). Discherodontus, a new genus of Cyprinid fishes from South-eastern Asia. Occassional Paper of Museum of Zoology, University of Michigan 718: 1-31.

Raj, B.S. (1941). Two new Cyprinid fishes from Travancore, South India, with remarks on Barbus (Puntius) micropogon Cuv. and Val. Records of the Indian Museum (Calcutta) 43(3): 375-386.

Rajan, S. (1955). Notes on a collection of fish from the headwaters of the Bhavani River, south India. Journal of the Bombay Natural History Society 53(1): 44-48.

Shrivana, R. (2013). Ray of hope for rare fish. Deccan Herald. http:// www.deccanherald.com/content/339301/ray-hope-rare-fish.html (Accessed on 28th June 2013)

Talwar, P.K. \& A.G. Jhingran (1991). Inland Fishes of India and Adjacent Countries. Vol 1 \& 2. A.A. Balkema, Rotterdam, 541pp.

Yang, M., V. Hirt, T. Sado, M. Arunachalam, R. Manickam, K.L. Tang, A.M. Simons, H. Wu, R. Mayden \& M. Miya (2012). Phylogenetic placements of the barbin genera Discherodontus, Chagunius, and Hypselobarbus in the subfamily Cyprininae (Teleostei: Cypriniformes) and their relationships with other barbins. Zootaxa 3586: 26-40. 